\title{
Antinuclear antibodies in ankylosing spondylitis, psoriatic arthritis, and psoriasis
}

\author{
J. N. ROSENBERG, G. D. JOHNSON, AND E. J. HOLBOROW \\ From the Bone and Joint Research Unit, London Hospital Medical College, London
}

SUMMARY Granulocyte-specific antinuclear antibodies (GS-ANA) were detected in the sera of 5 of 88 patients with ankylosing spondylitis (AS) and in 7 of 52 cases of psoriatic arthritis (PsA), but were not found in 91 patients with malignant or non-malignant chest disease nor in 25 cases of psoriasis. Organ non-specific ANA were present in serum from 6 cases of AS and 1 of PsA. None of the sera gave significant levels for soluble immune complexes as detected by a C1q-binding assay. O The presence of antinuclear antibodies was not associated with clinical features or drug therapy in $\cong$ either AS or PsA.

Antinuclear antibodies (ANA) generally do not show organ specificity and are detectable on a wide range of tissue substrates by the indirect immunofluorescent method. A notable exception is granulocyte-specific (GS) antibody, which reacts with nuclei of mature granulocytes (and monocytes) but not with nuclei of lymphocytes or cells of other tissues (Wiik and Munthe, 1972).

GS-ANA occur uncommonly in health (Wiik, 1976), and their highest incidence has been found in Felty's syndrome, rheumatoid arthritis, and systemic lupus erythematosus (Faber and Elling, 1966). In a previous study we reported the presence of GS antibody in $20 \%$ of cases of juvenile chronic arthritis (Rosenberg et al., 1975). Although the presence of autoantibodies is not considered to be a feature of ankylosing spondylitis (Eghtedari et al., 1976), Vasey and Kinsella (1977) detected leucocytereactive antinuclear antibodies in $60 \%$ of sera from 125 cases. In psoriatic arthritis (PsA) the incidence of organ-non-specific (ONS) ANA is low (Lambert et al., 1977), but we have noted the presence of granulocyte-specific antibody in some cases.

The aim of the present study was to determine the incidence of GS and ONS ANA in patients with AS, PsA, and psoriasis, and to determine whether the presence of ANA in these conditions was associated with other laboratory findings or with particular clinical features.

Accepted for publication 15 December 1978.

Correspondence to Professor E. J. Holborow, Bone and Joint Research Unit, London Hospital Medical College, 25-29 Ashfield Street, London E1 2AD.

\section{Materials and methods}

\section{PATIENTS}

Serum was obtained from 88 cases of established AS 52 cases of PsA (Moll and Wright, 1973), and 23 cases of psoriasis not associated with arthritis. No patient was leucopenic (leucocytes $<4 \times 10^{9} / 1$ ). Ninty-one patients with malignant and nonmalignant diseases of the chest served as controls.

\section{LEUCOCYTE PREPARATIONS}

Ethanol-fixed cytocentrifuge preparations of human leucocytes from a healthy person were prepared as previously described (Rosenberg et al., 1975). The blood group of the donor was shown to be unim-? portant (Rosenberg, unpublished). Substrate slides were stored at $-20^{\circ} \mathrm{C}$.

\section{STAINING PROCEDURE}

Sera were randomised and tested for the presence of 음 ANA by indirect inmumofluorescence (IF) with a serum dilution of $1: 10$ for GS-ANA and 1:10, 1:40 for ONS ANA on cryostat sections of rat liver. $N$ Known positive and negative sera were included in each batch. Fluorescein-labelled conjugates-anti Ig, IgA, IgM, and IgG (Wellcome Reagents)-were $\omega$ used at their optimum working dilutions determined by block titration. Stained preparations wereco mounted in buffered glycerol pH 8 and immediately $\mathbb{D}$ read without knowledge of their identity by one ${ }^{-}$ observer (J.N.R.) on a Reichert microscope equipped $\frac{T}{T}$ with transmitted dark-ground illumination. The

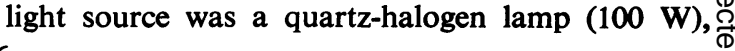


primary filter Balzer FITC 3 supplemented with BG 38 (Schott and Gen) and secondary filter KodakWratten 12.

Each serum was tested on at least 2 occasions and considered positive only if a positive result was obtained in 2 consecutive tests. This eliminated a small number of doubtful reactions. Sera found to be positive were immediately divided and stored at $-20^{\circ} \mathrm{C}$ for further study. Those from cases of AS and PsA were titrated in a doubling dilution series with anti-Ig conjugate. Complement binding activity was determined by adding fresh human plasma (stored at $-70^{\circ} \mathrm{C}$ ) to the diluted serum and staining with anti C3 conjugate (Johnson et al., 1978).

Tests for ONS ANA were standardised by reference to the WHO International Reference Preparation for Antinuclear Factor 66/233.

\section{ANTI-DNA ANTIBODIES}

A modified Farr test using calf thymus DNA labelled with tritiated actinomycin-D (Johnson and Holborow, 1977) was performed on sera which gave peripheral nuclear staining in the IF test.

The presence of soluble circulating immune complexes was detected using a ${ }^{125} \mathrm{I}-\mathrm{Clq}$ binding method (Zubler et al., 1976).

\section{Results}

Granulocyte-specific ANA were detected in the serum from 5 patients with AS $(6 \%)$ and 7 with PsA $(13 \%)$ as shown in Table 1 . They were not detected in any of the cases of psoriasis or in chest disease controls. No nuclear staining of eosinophils (which are readily recognised under the fluorescent microscope) nor of monocytes was observed with sera that were GS-ANA positive. Other characteristics are shown in Table 1. None of the positive sera showed complement fixation, and a peripheral

Table 1 Granulocyte-specific ANA in ankylosing spondylitis and psoriatic arthritis

\begin{tabular}{|c|c|c|c|c|c|c|c|}
\hline & No. & $\begin{array}{l}\text { Positiv } \\
\text { No. }\end{array}$ & $\begin{array}{l}v e \\
\%\end{array}$ & Titre & Pattern* & Ig class & $C^{\prime}$ \\
\hline $\begin{array}{l}\text { Ankylosing } \\
\text { spondylitis }\end{array}$ & 88 & 5 & 6 & $\begin{array}{c}>1: 640 \\
1: 160 \\
1: 40 \\
1: 20 \\
1: 20\end{array}$ & $\begin{array}{l}\mathbf{P} \\
\mathbf{P} \\
\mathbf{P} \\
\mathbf{D} \\
\mathbf{D}\end{array}$ & $\begin{array}{l}G \\
G, M \\
(A) * * \\
M \\
M(A)\end{array}$ & $\frac{-}{-}$ \\
\hline $\begin{array}{l}\text { Psoriatic } \\
\text { arthritis }\end{array}$ & 52 & 7 & 13 & $\begin{array}{c}>1: 640 \\
1: 40 \\
1: 40 \\
1: 20 \\
1: 20 \\
1: 10 \\
1: 10\end{array}$ & $\begin{array}{l}\mathbf{P} \\
\mathbf{D}, \mathbf{P} \\
\mathbf{D}, \mathbf{P} \\
\mathbf{P} \\
\mathbf{D}, \mathbf{P} \\
\mathbf{D} \\
\mathbf{P}\end{array}$ & $\begin{array}{l}G \\
G \\
G \\
G \\
A \\
G \\
G \\
G\end{array}$ & $\begin{array}{l}- \\
- \\
- \\
-\end{array}$ \\
\hline
\end{tabular}

*P= Peripheral; $\mathbf{D}=$ diffuse. $\left.^{* *(}\right)=$ weak reaction.
Table 2 Incidence of organ-non-specific ANA in ankylosing spondylitis, psoriatic arthritis and psoriasis

\begin{tabular}{|c|c|c|c|c|c|}
\hline & \multirow[t]{2}{*}{ No. } & \multicolumn{2}{|c|}{$\begin{array}{l}\text { Titre } \\
1: 10=6 \mathrm{U} / \mathrm{ml}\end{array}$} & \multicolumn{2}{|c|}{$1: 40=25 \mathrm{U} / \mathrm{ml}$} \\
\hline & & No. & $\%$ & No. & $\%$ \\
\hline Ankylosing spondylitis & 36 & 9 & 25 & 6 & 17 \\
\hline Psoriatic arthritis & 32 & 6 & 19 & 1 & 3 \\
\hline Psoriasis & 25 & 9 & 36 & 0 & 0 \\
\hline
\end{tabular}

pattern of nuclear staining was not associated with increased DNA-binding.

ONS ANA detectable on rat liver sections were present in 6 cases of AS $(17 \%)$ and 1 of PsA (3\%) at a level equivalent to 25 units $/ \mathrm{ml}$. Lower levels (6 units $/ \mathrm{ml}$ ) were detected in 9 further cases of AS $(25 \%), 6$ of PsA $(19 \%)$, and 9 of psoriasis $(36 \%)$.

None of the sera tested showed binding of $\mathrm{C} 1 \mathrm{q}$ above the normal range.

Patients with AS and PsA who had either GsANA or ONS ANA did not differ from those who were ANA negative with regard to sex, age of onset, duration of disease, peripheral joint involvement, uveitis, tissue type, treatment with drugs, or radiotherapy.

\section{Discussion}

The low incidence of granulocyte-specific ANA found in this study in ankylosing spondylitis does not accord with the report of Vasey and Kinsella (1977), who found leucocyte-reactive ANA in 60\% of 125 cases. These authors used unfixed, aged buffy coat leucocytes as substrate, but using a similar preparation we were unable to confirm their finding. Detection of GS-ANA requires nuclei to be damaged by repeated freezing and thawing as originally described by Elling (1967) or by treatment with alcohol (Wiik and Munthe, 1972), and this might account for the low incidence of leucocyte-reactive ANA found by Vasey and Kinsella (1977) in their rheumatoid arthritis control group.

Eosinophil-specific ANA, which we have previously reported in some cases of juvenile chronic arthritis and adult RA (Rosenberg et al., 1975), were not detected in the present study. This might be of diagnostic value.

Our finding of $25 \mathrm{U} / \mathrm{ml}$ ONS ANA in $17 \%$ of AS cases is not in agreement with the reports of Eghtedari et al., (1976) and Vasey and Kinsella (1977), who found a low incidence. This may reflect different levels of sensitivity in the detection systems employed and underlines the relevance of the international reference preparation to comparison of results of ANA tests obtained in different laboratories.

Although GS-ANA have been reported in healthy 
subjects with a similar frequency to ONS ANA (less than $10 \%$ ) by Wiik (1976), we did not find GS-ANA in healthy controls or patients with non-rheumatic disease previously studied (Rosenberg et al., 1975). Their occurrence in $13 \%$ of cases of psoriatic arthritis in this study is therefore of interest. Such antibodies may have pathogenic significance in joint disease, since their presence in synovial fluid from rheumatoid joints has been reported by Elling $e t$ al. (1968).

A significant level of ONS ANA (25 U/ml) was found in only 1 case of PsA, in agreement with the findings of Lambert et al. (1977) and in no case of psoriasis.

The pattern of nuclear staining obtained with many of the GS-ANA-positive sera was peripheral. This pattern with nuclei in tissue sections has been attributed to the presence in the serum of antibodies specific for DNA (Rothfield and Stollar, 1967), though we have not been able to show this association (Johnson and Holborow, unpublished). Further, we did not find increased DNA-binding capacity in any of the sera that gave peripheral GS-ANA staining.

The absence of soluble immune complexes detectable by a Clq binding assay from all the groups studied conflicts with the finding of Braun-Falco et al. (1977), who detected complexes by a similar technique in $70 \%$ of cases of psoriasis and in $8 \%$ of controls. Corrigall et al. (1978), using an antibodymediated lymphocyte-induced cytotoxicity test, detected complexes in $61 \%$ of 18 cases of ankylosing spondylitis. These discrepancies are unexplained. The presence of antinuclear antibodies in this study could not be shown to identify clinical subgroups within the diseases studied, and their significance in the individual patient remains unexplained.

The control sera were kindly provided by Professor D. A. Price Evans for investigation of immune complexes. We thank Mrs Bernadette Thompson for carrying out the Clq binding tests.

\section{References}

Braun-Falco, O., Mannel, C., and Scherer, R. (1977). Nachweis von zirkulierenden Ioslichen immunkomplexes in serum von psoriasispatienten mit dem ${ }^{125} \mathrm{I} \mathrm{Clq}$ ablenkungstest. Hautarzt, 28, 658-660.
Corricall, V., Panayi, G. S., Unger, A., Poston, R. N., and Williams, B. D. (1978). Detection of immune complexes in serum of patients with ankylosing spondylitis. Annals of the Rheumatic Diseases, 37, 159-163.

Eghtedari, A. A., David, P., and Bacon, P. A. (1976). Immunological reactivity in ankylosing spondylitis. Circulating immunoblasts, autoantibodies, and immunoglobulins. Annals of the Rheumatic Diseases, 35, 155-157.

Elling, P. (1967). Reaction of antinuclear factor with poly- $\bar{\nabla}$ morphonuclear granulocytes. 2: On the inaccessibility of $\varrho$ intact leucocytes to granulocyte-specific ANF of high क molecular weight. Acta Pathologica et Microbiologica Scandinavica, 69, 384-392.

Elling, P., Grandal, H., and Faber, V. (1968). Granulocytespecific antinuclear factors in serum and synovial fluid in rheumatoid arthritis. Annals of the Rheumatic Diseases, 27, 225-232

Faber, V., and Elling, P. (1966). Leucocyte-specific antinuclear factors in patients with Felty's syndrome, rheumatoid arthritis, systemic lupus erythematosus and other diseases. Acta Medica Scandinavica, 179, 257-267.

Johnson, G. D., and Holborow, E. J. (1977). Methods for $\sigma$ detecting antibodies to dsDNA. Annals of the Rheumatic 음 Diseases, 36, suppl., 87-89.

Johnson, G. D., Holborow, E. J., and Dorling, J. (1978). Immunofluorescence and Immunoenzyme Techniques. In Handbook of Experimental Immunology, 3rd edn., p. 15 17. Edited by D. M. Weir. Blackwell Scientific Publications: Oxford.

Lambert, J. R., Scott, G., and Wright, V. (1977). Psoriatic arthritis and antinuclear factor. British Journal of Derm\& tology, 96, 11-14.

Moll, J. M. H., and Wright, V. (1973). Psoriatic arthritis Seminars in Arthritis and Rheumatism, 3, 55-78.

Rosenberg, J. N., Johnson, G. D., Holborow, E. J., and Bywaters, E. G. L. (1975). Eosinophil-specific and other granulocyte-specific antinuclear antibodies in juvenile chronic polyarthritis and adult rheumatoid arthritis. Annals of the Rheumatic Diseases, 34, 350-353.

Rothfield, N. G., and Stollar, B. D. (1967). The relationship of immunoglobulin class, pattern of antinuclear antibody, and complement fixing antibodies to DNA in sera from patients with systemic lupus erythematosus. Journal of Clinical Investigation, 46, 1785-1794.

Vasey, F. B., and Kinsella, T. D. (1977). Increased frequency of leucocyte-reactive antinuclear antibody in patients with ankylosing spondylitis. Journal of Rheumatology, 4, 158164.

Wiik, A. (1976). Antinuclear factors in sera from healthy blood donors. Acta Pathologica et Microbiologica Scandinavica, Sect. C, 84, 215-220.

Wiik, A., and Munthe, E. (1972). Restrictions among heavy and light chain determinants of granulocyte-specific antinuclear factors. Immunology, 23, 53-60.

Zubler, R. H., Lange, G., Lambert, P. H., and Miescher, P. A. (1976). Detection of immune complexes in unheated sera by modified ${ }^{125} \mathrm{I}$ Clq binding test. Journal of Immunology, o 116, 232-235. 